\title{
The first report of a Salmonella enterica serovar Havana phage and its lytic activity at storage temperature of processed chicken
}

\author{
Ramon Arvin Noriel B. Santos ${ }^{1}$, Mary Anne Claudine S.P. Avena ${ }^{1}$, Rose Elaine J. Gumafelix', \\ Gillian Anthony A. Mamuric ${ }^{1}$, Anna Kristina D. Pastoral ${ }^{1}$, E Donna May D. Papa ${ }^{1,2 *}$ \\ ${ }^{1}$ Department of Biological Sciences, College of Science \\ ${ }^{2}$ Research Center for the Natural and Applied Sciences \\ University of Santo Tomas \\ España Boulevard, 1015 Manila, PHILIPPINES
}

\begin{abstract}
Salmonella enterica serovar Havana was isolated from raw, unprocessed chickens. A bacteriophage, designated as Bacteriophage A3CE, capable of lysing $S$. Havana was isolated from soil. It possesses an icosahedral head, a contractile tail, and linear, double-stranded DNA genome classified under the Family Myoviridae. There was a $>90 \%$ reduction in the number of host, given that the ratio of phage A3CE to $S$. Havana was 10 or more (MOI>10), $6 \mathrm{~h}$ after the bacteriophage was introduced to the host at room temperature. Phage A3CE and its host were mixed and incubated at both room temperature and $4^{\circ} \mathrm{C}$ (same concentration for both temperatures). Results show that there is no significant difference between the activity of the isolated phage at room temperature and at $4^{\circ} \mathrm{C}(p>0.05)$. Thus, Phage A3CE was effective in reducing the number of $S$. Havana at both temperature conditions making it a promising alternative agent against the said bacterium. This was the first study to document $S$. Havana phages and was the first recorded Salmonella phage in the Philippines.
\end{abstract}

Keywords: Salmonellosis, Myoviridae, Multiplicity of Infection, storage temperature, room temperature

\section{INTRODUCTION}

Food-borne diseases has been and currently is a global problem, with roughly 48 million people $\left(1 / 6^{\text {th }}\right.$ of the population) are infected annually in the United States [1]. The steady incline of several food-borne diseases caused by Salmonella, Campylobacter, Escherichia coli, Listeria, and other bacterial pathogens that impact public health, prove that the current

*To whom correspondence should be addressed dmadzp1010@yahoo.com technologies employed to inactivate them in food are not infallible and can be compromised [2].

Salmonella is a Gram-negative, rod-shaped, facultatively anaerobic, motile, non-spore forming bacterium of the Family Enterobacteriaceae, also known as enteric bacteria. Salmonellae reside in the intestinal tract of humans and animals [3]. Salmonellosis is the disease caused by these bacteria which can range from bacterial diarrhea to septicemia [4]. 
Consumption of contaminated foods is the usual route of the disease. The avian species have been frequently implicated as the major source of Salmonellosis. In 2004, it was reported as the most frequent causative agent of food-borne bacterial infection based from the Food Diseases Active Surveillance [5].

Salmonella enterica serovar Havana was first reported in 1937 during an outbreak of meningitis in a maternity hospital where 21 newborns came down with severe purulent meningitis and all of these were accounted as fatal within one to three days. Moreover, according to the Foodborne Illness Outbreak Database, an outbreak of $S$. Havana was also accounted in Georgia during 1987 wherein chicken was the implicated vehicle [6].

Bacteriophages are viruses that infect bacterial cells and multiply within them. They are capable of lysing specific bacterial strain by penetrating through their cell membrane and disrupting metabolic processes [7]. The therapeutic use of lytic bacteriophages to treat pathogenic bacterial infections is implied through bacteriophage therapy. Lytic phages are the most suitable candidates for phage therapy because they quickly reproduce within and lyse the bacteria in their host range, growing exponentially in number during the process [8].

The use of bacteriophages to control pathogens in foods is relatively new compared to their use in therapeutic and diagnostic application. Phage bio-control in foods has been investigated primarily in fresh produce, dairy, and meat products [8]. Bio-control of bacteria during industrial processing can be done by the application of phages directly on the surface of foods. Data obtained from experiments suggests that phages are very effective in controlling bacterial growth but lose effectiveness in nongrowing bacteria. To remedy these cases, applying high titers of phages can be performed to control pathogens by "lysis from without" mechanisms [12].

The potential use of safe, clean, and innovative bio-control agents such as lytic bacteriophages is gaining importance as the industry looks for an alternative to chemical-based compounds which when consumed frequently in high amounts may cause side-effects [5]. In this study, the potential of a bacteriophage to effectively lyse Salmonella under storage temperature was determined.

\section{EXPERIMENTAL}

Collection of chicken samples. Thirty (30) chicken intestine samples from newly eviscerated chickens collected from a Dressed Chicken and Processing Plant located in Loma de Gato Marilao, Bulacan were placed into 30 different sterile polypropylene plastic bags. An electric sealer was then used to seal each plastic bag. After sealing, these were placed inside ziplock bags and stored in cooler with ice $\left(\sim 4^{\circ} \mathrm{C}\right)$ and were immediately transported to the laboratory for processing.

Bacterial organism. Isolation of Salmonella was done using the ISO method 6579:2002. Twenty-five (25) grams of each chicken sample were pre-enriched in $225 \mathrm{~mL}$ of Buffered Peptone water for $24 \mathrm{~h}$ at $37^{\circ} \mathrm{C}$. Selective enrichment followed where $0.1 \mathrm{~mL}$ of the pre-enriched sample was added to a tube containing $10 \mathrm{~mL}$ of Rappaport-Vassiliadis broth and $1 \mathrm{~mL}$ of the preenriched sample was added to a tube containing $9 \mathrm{~mL}$ Tetrathionate broth. The enrichment broths were then incubated at $41.5^{\circ} \mathrm{C}$ for $24 \mathrm{~h}$ for the Rappaport-Vassiliadis broth and at $37^{\circ} \mathrm{C}$ for $24 \mathrm{~h}$ for the Tetrathionate broth. The enrichment broths were then plated on Brilliant Green Agar (BGA) and Xylose Lysine Desoxycholate Agar (XLDA) and were incubated for $24 \mathrm{~h}$ at $37^{\circ} \mathrm{C}$. Colonies resembling Salmonella colonies were picked using an inoculating loop and were purified on the same medium. Pure, presumptive Salmonella colonies were then grown on 
Nutrient Agar (NA) and were subjected to different biochemical tests and serotyping for confirmation [10].

The biochemical tests performed (in accordance to ISO 6579:2002 and Bergey's Manual of Determinative Bacteriology) to verify the identity of the presumptive Salmonella colonies were sugar utilization (Glucose, Sucrose, and Lactose) and $\mathrm{H}_{2} \mathrm{~S}$ production (TSIA), Urea Hydrolysis, Lysine Decarboxylation, Voges-Proskauer reaction, and Indole production.

Colonies confirmed to be Salmonella through biochemical testing were inoculated on a Tryptic Soy Agar (TSA) slant and were sent to the Research Institute for Tropical Medicine (RITM) in Alabang, Muntinlupa, Philippines for serotyping.

\section{Isolation and purification of bacteriophage.}

The agar layer method was used for the isolation, purification, and high titer preparation of bacteriophages lytic for Salmonella spp. [1113].

Transmission electron microscopy (TEM) of phages. Purified bacteriophage filtrates were sent to the Pathology Department, Research Institute for Tropical Medicine (RITM) in
Alabang, Muntinlupa for TEM. The electron micrographs were taken using Jeol 1220 transmission electron microscope under 40,000x and 60,000× magnification and underwent negative staining using phosphotungstate (PT) reagent afterwards.

\section{Designing a range of Multiplicities of Infection} (MOIs) and assessing its effect on the number of Salmonella spp. A 33 matrix (Table 1) of PFU/ $\mathrm{mL}$ against $\mathrm{CFU} / \mathrm{mL}$ was used to cover a range of MOIs. The MOI was used to describe the ratio of phage to bacteria and in this instance; ratios ranging from 0.01 to 10,000 was employed. The matrix was then used to analyze the effects of administering various phage titres $\left(10^{6}, 10^{7}\right.$, and $10^{8} \mathrm{PFU} / \mathrm{mL}$ ) to a range of Salmonella spp. concentrations $\left(10^{4}, 10^{6}\right.$, and $\left.10^{8} \mathrm{CFU} / \mathrm{mL}\right)$ [14].

Every combination of phage and Salmonella on the matrix were prepared. At certain intervals: $0,6,12,18$, and $24 \mathrm{~h}$. The number of surviving Salmonella spp. were enumerated by preparing decimal dilutions and were spread on XLD plates.

Comparison of bacteriophage activity at $4^{\circ} \mathrm{C}$ and at room temperature. One (1) $\mathrm{mL}$ of the phage filtrate was added to 5-h old Salmonella spp. in TSB. The mixture was stored in a
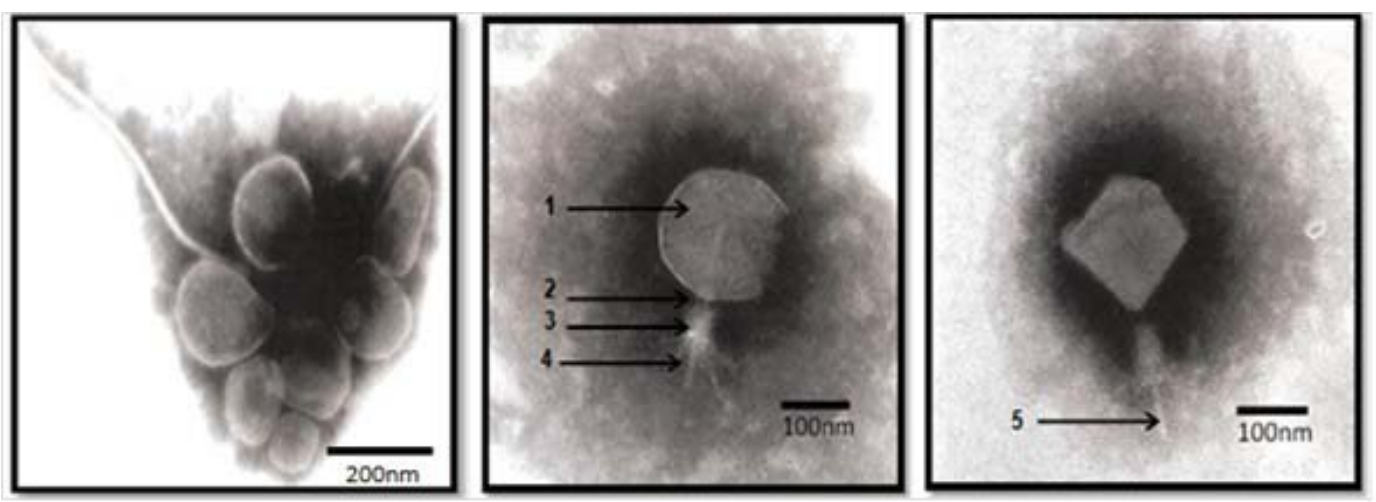

Figure 1. Transmmission electron micrograph of Phage A3CE: PT, 40,000x, cluster of seven phages (A); PT, 60,000x, showing icosahedral head with contractile sheath and six fibers (B); and, PT, 60,000x, showing icosahedral head with contractile sheath and one pin (C). 1. Nucleocapsid, 2. Collar, 3. Protein sheath, 4. Tail fibers, 5. Tail pin 
container stored at $4^{\circ} \mathrm{C}$. Another similar mixture was stored at room temperature and served as the control. Once the mixtures were stored, this was considered as time 0 . At certain intervals: 0 , $6,12,18$, and $24 \mathrm{~h}$, the mixtures were subjected to plaque assay using the agar overlay method $[1,14]$. The results were used to determine whether the storage temperature $\left(4^{\circ} \mathrm{C}\right)$ had a significant effect on the efficacy of the bacteriophage in comparison to that of under room temperature condition.

Data collection and analysis. In order to determine the efficacy of bacteriophage against $S$. Havana under $4^{\circ} \mathrm{C}$ storage temperature versus storage at room temperature $\left(25^{\circ} \mathrm{C}\right)$, data gathered were subjected to $t$-test $(\alpha=0.05)$

\section{Results AND DISCUSSION}

\section{Bacteria}

All 30 samples yielded presumptive Salmonella colonies on XLDA and BGA, the two selective medium used for isolation. The Salmonella resembling colonies were further subjected to biochemical tests for confirmation. Overall results of the biochemical test of all the isolates were consistent to show that it is confirmed as Salmonella spp. (Positive for Glucose Fermentation, $\mathrm{H}_{2} \mathrm{~S}$ production, and Lysine Decarboxylation, and Negative for Sucrose and Lactose Fermentation, Urea Hydrolysis, Voges Proskauer Reaction, and Indole Reaction) [10].

Two isolates were randomly chosen and was sent to the RITM for serotyping. The results showed that the serotype of both isolates was $S$. Havana. This confirms the probability of isolation of $S$. Havana in chickens which is the usual carrier of this kind of organism [6]. This isolation, though, is the first of its kind being isolated in poultry in the country which implicates its presence in the poultry population in the industry. This may not account to the frequency of the organism but its presence definitely implies the possibility of acquiring diseases caused by this organism like meningitis in neonates [6]. If not properly controlled, an outbreak is possible in consumers who are unaware of its possible threat.

\section{Isolation of bacteriophage}

Phage filtrate. The filtrates positive for the presence of bacteriophages as shown by the expression of plaques in plates, were obtained from filtering enriched samples using $0.45 \mu \mathrm{m}$ and $0.22 \mu \mathrm{m}$ Acrodisc syringe filters and confirming through spot plate method.

Plaque expression. The phage filtrates were subjected to plaque assay method (agar layer method) which allowed distinct characterization of plaques and convenient isolation and purification of bacteriophages. The selected plaque were picked and purified on a bacterial lawn of a 5-h old $S$. Havana. Among the phage filtrates, the group picked the filtrate of MG (small) and its corresponding phage was given the designation A3CE. This is because the plaques formed by Phage A3CE are clear and defined. Clear plaques indicate that the phage is lytic [15]. Plaques formed by Phage A3CE indicate that this bacteriophage was more efficient in lysing its host compared to the other phages. The size of the plaques of Phage A3CE was around $2 \mathrm{~mm}$ and appeared as early as $6 \mathrm{~h}$ in the solid medium after the plaque assay. The plaques also did not increase in size after $24 \mathrm{~h}$, distinguishing them from plaques formed by $B$. dellovibrio which continue to increase in size until it cleared the entire lawn of the bacterial host.

TEM. Phage A3CE (Fig. 1) is a tailed phage, and a member of the Order Caudovirales. The Order Caudovirales are divided into three families namely: Myoviridae, Siphoviridae, and Podoviridae. Members of the Family Myoviridae have contractile tails consisting of a sheath and a central tube (with at least 1250 observations and accounts for $25 \%$ of the tailed phages) [15]. Phage A3CE has an icosahedral 


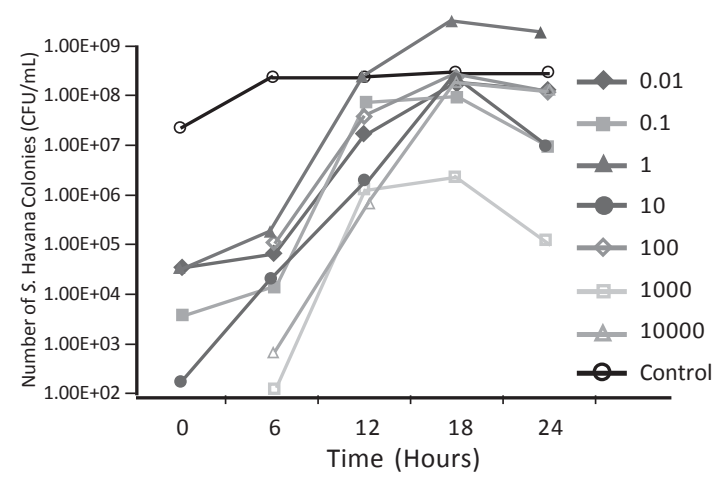

Figure 2. Number of recoverable $S$. Havana colonies (CFU/ml) per MOI.

head measuring $125 \mathrm{~nm}$, a collar, a contractile tail with a measuring of $65 \mathrm{~nm}$, tail fibers, and a tail pin.

\section{Bacteriophage activity at $40^{\circ} \mathrm{C}$}

The activity of bacteriophage at $4^{\circ} \mathrm{C}$ was compared with the bacteriophage activity under room temperature $\left(25^{\circ} \mathrm{C}\right)$ by testing the efficiency of the bacteriophage to lyse its host cell through plaque formation. Statistical treatment on the obtained results using two-tailed $t$-test yielded a $p$-value of 0.903896, indicating that there was no significant difference on the effects of both temperature sets on the lysing capability of the bacteriophage. This means the test temperature, $4^{\circ} \mathrm{C}$, only delayed the bacteriophage in lysing the $S$. Havana colonies that is why the number of bacteriophage was slightly lower compared to room temperature. However, it did not adversely affected the bacteriophage in its lysing capabilities, making it a suitable biocontrol agent in food products since $4^{\circ} \mathrm{C}$ is a common storage temperature. This result is consistent with other studies wherein phages remained viable and no significant decrease in their lytic capability after being subjected to storage temperature [14, 16, 17].

Multiplicity of infection is simply the ratio of the density of the bacteriophage to the density
Table1. Multiplicities of Infection (MOls)

\begin{tabular}{|c|c|c|c|}
\hline \multirow{2}{*}{$\begin{array}{l}\text { Salmonella spp. } \\
\text { Inoculum } \\
\text { (CFU/mL) }\end{array}$} & \multicolumn{3}{|c|}{$\begin{array}{l}\text { Bacteriophage Inoculum } \\
\text { (PFU/mL) }\end{array}$} \\
\hline & $10^{8}$ & $10^{7}$ & $10^{6}$ \\
\hline $10^{8}$ & 1 & 0.1 & 0.01 \\
\hline $10^{6}$ & 100 & 10 & 1 \\
\hline $10^{4}$ & 10,000 & 1,000 & 100 \\
\hline
\end{tabular}

of its bacterial host cells [15]. The set-up used in the experiment covered MOI values ranging from 0.01 to 10,000 (Table 1). The results (Fig. 2) obtained showed that there is an observable log phase of bacterial cells during its first 12-h incubation. However, at the 18 -h period, there is a significant decrease in number of cells which indicates that the bacteriophage achieved its maximal burst size, consequently leading to the decline in number of the bacterial colonies. The decline in number of bacterial colonies was because of the applied bacteriophage and not the natural death phase of the bacteria is because the negative control only reached the stationary phase and not the death phase.

There are $>90 \%$ reductions in the number of $S$. Havana colonies on MOI greater than 10, except for MOI 1000. This is parallel to the results of another study wherein there are greater than 2 $\log _{10}$ reductions of bacteria on MOI's 10 or above [13]. Through these data, it can be inferred that bacteriophage A3CE is effective in reducing the numbers of $S$. Havana. A factor that contributes to this efficacy is the number of bacteriophage applied to the bacterial mixture. The use of bacteriophage in excess to the bacterial concentration (in the case of this study, an MOI of 10) proved to be crucial in reducing the number of $S$. Havana colonies. This suggests that the use of bacteriophage A3CE as a bio-control agent exhibits a passive therapeutic effect. Under these conditions the initial phage dose is sufficiently in excess of the target bacterium population to cause reductions without the need for the bacteriophage to replicate and complete their life cycle. 


\section{CONCLUSION}

A bacteriophage, designated as Phage A3CE, lytic for an isolated Salmonella spp. (later identified as $S$. Havana) was isolated. This is the first Salmonella spp. phage to be isolated and studied in the Philippines. This is also the first study to isolate a phage specifically for the $S$. Havana serotype.

The efficacy of Phage A3CE in lysing $S$. Havana at $4^{\circ} \mathrm{C}$ was compared to that of room temperature $\left(25^{\circ} \mathrm{C}\right)$ by computing their respective $\mathrm{PFU} / \mathrm{mL}$ after $24 \mathrm{~h}$. Statistical analysis shows that there is no significant difference on phage activity at $4^{\circ} \mathrm{C}$ and at room temperature $\left(25^{\circ} \mathrm{C}\right)$ meaning that storage temperature does not hinder the lysing capabilities of Phage A3CE. A $3 \times 3$ matrix of MOI was also designed to determine which ratios were effective. At MOIs $>10$, there is a $>90 \%$ reduction on the recoverable $S$. Havana colonies. This implies that at ratios 10:1 or higher, Phage A3CE was effective in reducing the numbers of $S$. Havana and therefore can potentially serve as a viable bio-control alternative to chemical preservatives.

\section{REFERENCES}

[1] Centers for Disease Control and Prevention. Food Safety 2013 (http://www.cdc.gov/ foodsafety).

[2] Garcia P, Martinez B, Obezo J, Rodriguez A. Bacteriophages and their application in food safety. Letters in Applied Microbiology 2008; 47:479-485.

[3] Todar K. Online textbook of Bacteriology. (Wisconsin: University of Wisconsin, 2009).

[4] McLandsborough L. Food Microbiology. (USA: CRC Press, 2005).

[5] Mukhopadhyay S, Ramaswamy R. Application of emerging technologies to control Salmonella in foods: a review. Food Research International 2011 (DOI:10.1016/j.foodres.2011.05.016).

[6] Backer H, Boetani J, Werner S, Abbot S, Farrar $\mathrm{J}$, Vugia D. High incidence of extra-intestinal infections in a Salmonella Havana outbreak associated with alfalfa sprouts. Public Health Reports 2000; 115:339-345.
[7] Meyer G. Microbiology and Immunology Online, University of South Carolina School of Medicine 2010 (February 11, 2014: http:// pathmicro.med.sc.edu/mayer/phage.htm).

[8] Hudson JM, Mclntyre L, Billington C. Application of bacteriophages to control pathogenic and spoilage bacteria in food processing and distribution. In: Sabour P. \&. Bacteriophages in the Control of Food-and Waterborne Pathogens, pp.119-136. (Washington DC: ASM Press, 2010).

[9] Sillankorva S, Oliveira $\mathrm{H}$, Azeredo J. Bacteriophages and Their Role in Food Safety. International Journal of Microbiology 2012; 113.

[10] Zadernowska A, Chajêcka-Wierzchowska W, Klêbukowska L, Laniewska-Trokenheim L. Salmonella detection in poultry meat - validation of VIDAS Xpress automatic enzyme-linked fluorescent immunoassay-based method. Journal of Food Safety 2012; 32(4):407-414.

[11] Adams M. Bacteriophages. (New York: Interscience Publishers, Inc, 1959).

[12] Twest R, Kropinski AM. Bacteriophage enrichment from water and soil. Methods in Molecular Biology 2009; 501:15-21.

[13] Berchieri Jr A, Lovell MA, Barrow PA. The activity in the chicken alimentary tract of bacteriophages Iytic for Salmonella typhimurium. Res. Microbiol. 1991; 142:541-549.

[14] Hooton SP, Atterbury RJ, Connerton IF. Application of a bacteriophage cocktail to reduce Salmonella typhimurium U288 contamination on pig skin. International Journal of Food Microbiology 2011; 151:157-163.

[15] Kutter E, Sulakvelidze A. Bacteriophages: Biology and Applications. (Boca Raton: CRC Press, 2005).

[16] Bigot B, Lee W, McIntyre L, Wilson T, Hudson J, Billington $\mathrm{C}$, et al. Control of Listeria monocytogenes growth in a ready-to-eat poultry product using a bacteriophage. Food Microbiology 2011; 28:1448-1452.

[17] Soni K, Nannapaneni R. Bacteriophage Significantly Reduces Listeria monocytogenes on Raw Salmon Fillet Tissue. Journal of Food Protection 2009; 73:32-38. 